\title{
ГРОМАДСЬКЕ ЗДОРОВ’Я
}

DOI 10.31718/2077-1096.21.1.150

УДК 616.12-089:614.2

Іванюк А. В.

\section{КОНЦЕПТУАЛЬНІ НАПРЯМИ ФОРМУВАННЯ МОДЕЛІ РЕГІОНАЛЬНОГО ЦЕНТРУ КАРДІОЛОГІЇ ТА КАРДІОХІРУРГІЇ НА ПРИНЦИПАХ ДЕРЖАВНО-ПРИВАТНОГО ПАРТНЕРСТВА}

Київська обласна клінічна лікарня

Мета роботи: Обгрунтувати концептуальні напрями фрормування моделі регіонального центру кардіології та кардіохіруреії на принципах державно-приватного партнерства. Матеріали і методи. Для досягнення поставленої мети у роботі застосовувалися загальнонаукові методи аналізу, синтезу, узагальнення, інтерпретації наукових даних, а також системний $i$ структурнофункціональний підходи. Результати. Розроблені концептуальні напрями формування моделі регіонального центру кардіології та кардіохірургії на принципах державно-приватного партнерства згідно з Конституцією України, законами та іншими нормативно-правовими актами України, загальновизнаними принципами і нормами міжнародного права у галузі охорони здоров'я та з урахуванням вітчизняного та зарубіжного досвіду. Вони спираються на системний підхід і спрямовані на вирішення практичного завдання - організації діяльності регіонального центру кардіології та кардіохірургії на принципах державно-приватного партнерства. Таким чином, концептуальні напрями є одночасно і практичною методологією реалізації комплексного процесу моделювання регіонального центру кардіології та кардіохірургії і стратегією довгострокової взаємодії держави і бізнесу у вирішенні суспільно вагомої задачі розвитку інноваційної високотехнологічної кардіологічної допомоги населенню регіону. Висновки. Концептуальні напрями формують нову модель медичного закладу із залученням приватного капіталу, ринкових механізмів, забезпечують їй стійке економічне становище і можливість розвитку виробничої бази. Вони адресно спрямовані на оптимізацію правової, організаційної та виробничої структури регіонального центру кардіології та кардіохірургії, формування стійкого фрінансування, розвиток матеріально-технічної бази; створення сучасних механізмів ефективного управління, вдосконалення кадрової політики, підвищення доступності та якості медичних послуг.

Ключові слова: регіональний центр кардіології та кардіохірургії, державно-приватне партнерство.

\section{Вступ}

Хвороби системи кровообігу (ХСК) є основною причиною смерті та інвалідизації дорослого населення та населення працездатного віку в Україні, що обумовлює їх вагоме медикосоціальне та соціально-економічне значення $[1,2]$. Організація медичної допомоги хворим на ХСК становить одну із провідних проблем вітчизняної системи охорони здоров'я. У заклади охорони здоров'я щорічно здійснюється понад 85,0 млн звернень, третина з яких спричинена XCK [3].

У той же час в Україні «за більш ніж десятирічний період, не зазнали радикальних змін: - забезпечення доступної, якісної, кваліфікованої медичної допомоги всім громадянам, незалежно від їх соціально-економічного стану та місця проживання; - запровадження ефективної та прозорої моделі фінансування системи медичної допомоги, орієнтованої на реальні потреби пацієнтів; підвищення рівня та забезпечення сталості фрінансування галузі; вжиття заходів щодо запровадження в діяльність закладів охорони здоров'я сучасних економічних механізмів; - запровадження загальнообов'язкового державного соціального медичного страхування із забезпеченням належної якості гарантованих державою безоплатних медичних послуг; - запровадження дійових механізмів мотивації медичних працівників до якісного і ефективного надання медичних послуг» [4].

Дані проблеми зумовлюють актуальність проблеми пошуку механізмів спільного функціонування держави і бізнесу, оскільки саме взаємодія держави и приватного сектора були і продовжують залишатися основними господарюючими суб'єктами в охороні здоров'я понад 150 країн світу [5,6].

У країнах Заходу, успішним напрямком реформування охорони здоров'я стало державноприватне партнерство (ДПП), яке впродовж останніх трьох десятиліть стало найпопулярнішим способом управління конкуренцією в ринковій економіці. На сьогоднішній день у розвинених країнах до $60 \%$ проектів у галузі охорони здоров'я реалізуються у формі ДПП, що засвідчує його перспективність [7].

Актуальність дослідження обумовлена епіде- 
мічною ситуацією щодо ХСК в Україні, недостатньою забезпеченістю доступною, якісною, кваліфікованою медичною допомогою всіх верств населення, незалежно від їх соціальноекономічного стану та місця проживання, відсутністю ефективної і прозорої моделі фрінансування системи медичної допомоги, орієнтованої на реальні потреби пацієнтів, а також появою в Україні законодавчої бази для розвитку ДПП $[8,9,10]$.

\section{Мета дослідження}

Обґрунтувати концептуальні напрями формування моделі регіонального центру кардіології та кардіохірургії (РЦКК) на принципах державноприватного партнерства.

\section{Матеріали і методи дослідження}

Для досягнення поставленої мети у роботі застосовувалися загальнонаукові методи аналізу, синтезу, узагальнення, інтерпретації наукових даних, а також системний і структурнофункціональний підходи.

\section{Результати дослідження}

На основі аналізу наукових джерел було виявлено, що ДПП є тенденцією у загальносвітовій практиці розвитку охорони здоров'я.

Залучення приватного капіталу до сфери охорони здоров'я стало нормою і ефективним фактором впровадження у галузь інноваційних методів лікування і сучасного технологічного оснащення клінік, забезпечення якості медичної допомоги, формування цифрової системи охорони здоров'я. Все це актуалізує розробку концептуальних напрямів формування моделі РЦКК на принципах ДПП.

Впровадження механізмів ДПП є неможливим без урахування специфіки країни: організаційної структури, законодавства, інвестиційного клімату. Можливість організації установ охорони здоров'я на принципах державно-приватного партнерства в Україні обумовлена наступними законами: Закон України від 01.07.2010 № 2404-VI «Про державно-приватне партнерство» [8]; Закон України від 24.11.2015 № 817-VIII «Про внесення змін до деяких законів України щодо усунення регуляторних бар'єрів для розвитку державно-приватного партнерства та стимулювання інвестицій в Україні» [9]; Закон України від 06.04.2017 № 2002-VIII «Про внесення змін до деяких законодавчих актів України щодо удосконалення законодавства з питань діяльності закладів охорони здоров'я» [10].

У відповідності до чинної нормативної бази, організаційно-правовою формою ДПП, яка найбільше підходить для системи охорони здоров'я України, $є$ угода про державно-приватне партнерство. Реалізацію ДПП у нашому дослідженні ми розглядаємо у формі договору: створення володіння - управління - передача державі. Коли приватний партнер, згідно з умовами догово- ру, здійснює інвестиції у визначений об'єкт, після чого володіє та управляє ним у межах визначеного договором терміну, а після його завершення об'єкт передається державі.

Для формуванні моделі методологічно були виділені чотири складові: комплекс методів формування моделі, принципи моделювання, формування концептуальної структури моделі та технологія моделювання.

- Методи формування моделі. При формуванні моделі РЦКК на принципах ДПП були використані наступні методи: системного підходу та аналізу, бібліосемантичний, статистичний методи, метод експертних оцінок, концептуального моделювання, за допомогою яких здійснено аналіз ДПП в охороні здоров'я розвинених країн світу, аналіз захворюваності на ХСК в Україні та регіонах, системна інтеграція медичних структур регіону, які надають медичну допомогу хворим на ХСК, а також розроблена модель РЦКК.

Принципи моделювання РЦКК :

- Вивчення законів України про форми ДПП в охороні здоров'я та підзаконних актів, які визначають організаційно-правові основи взаємодії партнерів: держави і приватного інвестора.

- Розробка сучасної моделі РЦКК на принципах ДПП на основі системного інноваційного інтегрування виробничих структур, структур технологічних процесів, структури управління, зв'язку $з$ метою забезпечення населення регіону доступною високоспеціалізованою кардіологічною та кардіохірургічною допомогою;

- інтеграція у моделі РЦКК розглядається як:

- об'єднання двох служб - кардіологічної та кардіохірургічної допомоги, що забезпечують основну діяльність моделі в одному комплексі РЦКК; - інтеграція усередині цих служб відділень у лікувально - діагностичні центри з організацією та формуванням у них єдиних цілей; - об'єднання у РЦКК двох потоків пацієнтів, споживачів платних і безоплатних медичних послуг; - зовнішня інтеграція, договірне об'єднання консультативно-діагностичного відділення РЦКК з кардіологами у районних лікарнях (на договірних умоваx).

- Планування діяльності РЦКК, спрямованої на споживачів і задоволення їх потреб;

- Зосередження функціонування РЦКК на розвитку інноваційних процесів і ресурсів (фінансових, матеріально-технічних, кадрових тощо);

- Забезпечення якості та доступності гарантованих обсягів послуг для всіх верств населення регіону;

- Застосування технології адресного планування потужності РЦКК - поліклініки, ліжкового фонду і т.п. на основі аналізу специфічних для регіону даних (аналізу стану здоров'я населення Київської області, мережі кардіологічної служби та її ресурсної бази і т.п.).

- Концептуальна структура діяльності біз- 
нес - моделі РЦКК - це сукупність стратегії виробничого процесу на принципах ДПП, відповідних цілей і перспектив, сучасних технологічних процесів, управління, ресурсів (матеріально-технічних, фрінансових, кадрових), критеріїв визначення показників діяльності, ланцюжків створення цінностей всередині моделі РЦКК, медичних стандартів, прогнозних економічних результатів.

- Технологія моделювання - це синтез сукупності способів, прийомів заходів, функцій для досягнення бажаного результату за допомогою зазначених інструментів.

Заходи щодо нормативно-правового забезпечення

- Розробка Статуту РЦКК. Державна реєстрація РЦКК як державно - приватної установи охорони здоров'я, юридичної особи із самостійним балансом, розрахунковим та іншими рахунками в установах банків, з відособленим майном, печаткою зі своїм найменуванням, бланками, фрірмовим найменуванням.

- Розробка бізнес-плану - обґрунтування відповідальності за економічну ефективність діяльності (наскільки послуги будуть відповідати вимогам ринку, запитам пацієнтів).

- Забезпечення концентрації фрінансових коштів засновників (держави і приватного інвестора) і кадрових ресурсів на пріоритетних та інноваційних напрямках роботи РЦКК.

- Формування ринку медичних послуг, різного виду договірних робіт, платних послуг.

- Конкретизація державних гарантій надання громадянам певних видів безкоштовної медичної допомоги в РЦКК;

Організаційні заходи

- Розробка ефрективної структури, яка надає високоспеціалізовану медичну допомогу, - інтегрованої функціонально-організаційної моделі РЦКК заснованої на структурній диференціації з виділенням самостійних організаційних модулів.

- Обґрунтування ефрективної моделі інтегрованого управління РЦКК з організацією управління бізнеспроцесами, менеджменту медичних послуг і інтеграцією управління розрізненими об'єктами.

- Оснащення РЦКК сучасним лікувально-діагностичним обладнанням.

- Укомплектування РЦКК висококваліфокованими кадрами.

- Створення умов, можливостей і мотивації для якісної праці персоналу.

- Впровадження в РЦКК системи постійного навчання та вдосконалення медичних кадрів.

- Забезпечення розвитку комп'ютерної інформаційної системи для підтримки прийняття рішень.

- Оптимізація медико - економічних стандартів.

- Розробка і впровадження системи управління якістю медичної допомоги на основі стандартів її надання.

- Поетапне удосконалення надання медичної допомоги хворим з ХСК.

- Розвиток інновацій. Розширення обсягів та впровадження нових видів високотехнологічної допомоги.

- Гарантоване забезпечення усіх верств населення якісною доступною високотехнологічною медичною допомогою.

- Впровадження стандартів надання медичної допомоги.

- Уніфікація оснащення у відповідності до стандартів.

- Регулярна оцінка якості надання медичної допомоги.

Виробничі функції які мають забезпечити:

- Своєчасне надання високоспеціалізованої та висококваліфікованої медичної допомоги населенню, яка не може бути надана в інших медичних установах регіону.

- Консультативний прийом, амбулаторне та стаціонарне обстеження i лікування хворих на ХСК та їх реабілітація.

- Надання у повному обсязі невідкладної кардіохірургічної допомоги жителям регіону.

- Виконання хірургічних втручань і лікування хворих 3 коронарною недостатністю і супутньою патологією.

- Надання організаційноконсультативної допомоги кардіологам регіону щодо підвищення якості лікувально-профілактичної роботи на місцях, узагальнення передового досвіду і вдосконалення фрорм і методів надання медичної допомоги.

- Координація лікувальнопрофрілактичної та організаційнометодичної роботи, яка здійснюється кардіологами регіону.

- Виділення санітарного транспорту для екстреної та планової консультативної допомоги хворим.

- Проведення моніторингу епідеміологічної ситуації щодо ХСК та діяльності кардіологічної служби у регіоні кардіологів, розробка спільно з фахівцями обласного управління охорони здоров'я необхідних заходів щодо зниження захворюваності та підви- 
щення якості медичного обслуговування хворих на ХСК.

- Розробка стратегій первинної та вторинної профілактики ХСК.

- Впровадження сучасних організаційних технологій у практику надання швидкої та невідкладної допомоги пацієнтам з ХСК.

Таким чином, представлена методологія визначає основні концептуальні напрямки фрормування сучасної функціонально-організаційної, економічно стійкої бізнес-моделі РЦКК на принципах ДПП.

До того ж, бізнес-модель РЦКК при переході на принципи ДПП набуває статусу юридично і господарсько самостійної організації, яка має:

- державно-приватну організаційну форму, функціональні та ієрархічні зв'язки підрозділів;

- майновий - медико - технічний комплекс (певні матеріальні одиниці і відносини власності);

- виробничий комплекс (певні види діяльності, зв'язки, партнерів, замовників та ін.)

- структурований фрінансовий об'єкт (капітал, інвестиції, інвесторів, кредиторів та ін.)

- кадрово-організаційний комплекс (кадрову структуру, управління персоналом, навчання та перепідготовку персоналу).

У кінцевому рахунку, метою формування концептуальної моделі регіонального центру кардіології та кардіохірургії на принципах ДПП $є$ сприяння збільшенню тривалості життя населення і забезпечення задоволеності населення медичною допомогою у РЦКК.

\section{Висновки}

Концептуальні напрями формування моделі РЦКК на принципах ДПП є практичною методикою реалізації комплексного процесу моделювання нової моделі медичного закладу із залученням приватного капіталу, ринкових механізмів, стратегії довгострокової взаємодії держави і бізнесу у вирішенні суспільно вагомого завдання розвитку інноваційної високотехнологічної кардіологічної допомоги населенню регіону.

Концептуальні напрями спрямовані на оптимізацію правової, організаційної та виробничої структури РЦКК, фрормування стійкого фрінансування, розвиток матеріально-технічної бази; створення сучасних механізмів ефективного управління, вдосконалення кадрової політики, підвищення доступності та якості медичної допомоги.

У концептуальних напрямках дотриманий баланс публічних і приватних інтересів. Вагомою перевагою моделі РЦКК є забезпечення доступності для населення регіону високотехнологічної кардіологічної та кардіохірургічної допомоги.

Розроблені концептуальні напрями фрормування моделі РЦКК відповідають законодавчій базі України і $\epsilon$ «містом» до створення стійкого зв'язку між державою і приватними інвесторами.

Перспективи подальших досліджень полягають у використанні одержаних результатів для обґрунтування концептуальної моделі організації кардіологічної допомоги на принципах ДПП на регіональному рівні.

\section{Література}

1. Dudnyk SV, Koshelya II. Khvoroby systemy krovoobihu yak sotsial'no-medychna problema [Diseases of the circulatory system as a socio-medical problem]. Ukrayina. Zdorov"ya natsiyi. 2017; 3 (44): 20-1. (Ukrainian).

2. Kovalenko VM, Dorohoy AP. Sertsevo-sudynni khvoroby: medychno-sotsial'ne znachennya ta stratehiya rozvytku medychno-sotsial'ne znachennya ta stratehiya rozvytku
kardiolohiyi v Ukrayini [Cardiovascular diseases: medical and social significance and strategy of cardiology development in Ukraine]. Ukrayins'kyy kardiolohichnyy zhurnal. 2016; dodatok 3: 5-14. (Ukrainian).

3. Terenda NO. Khvoroby systemy krovoobihu ta sotsial'noekolohichni faktory ryzyku [Diseases of the circulatory system and socio-environmental risk factors]. Zdobutky klinichnoyi i eksperymental'noyi medytsyny. 2017; 3: 58-165. (Ukrainian).

4. Butova TV, Filatova TV, Arishkov AA. Zarubezhnyy opyt hosudarstvenno-chastnoho partnerstva [Foreign experience of public-private partnership]: abstracts of reports of International Scientific and Practical Congress: "Economic Development of the European Union and the UNS in the context of globalization ", Geneva, Switzerland, July 12-13, 2013. P. 241-7. (Russian).

5. Varnavskyy VH. Hosudarstvenno-chastnoe partnerstvo $V$ zdravookhranenyy: mezhdunarodnyy opyt [Public-private partnership in health care: international experience]. Upravlenye zdravookhranenyem. 2012; 1: 9 - 16. (Russian).

6. Rodnyanskyy DV, Valeeva GF. Hosudarstvenno-chastnoe partnerstvo $v$ sfere zdravookhranenyya: rehyonal'nyy analyz partnerstvo $v$ sfere zdravookhranenyya: rehyonal'nyy analyz
[Public-private partnership in health care: a regional analysis]. [Public-private partnership in health care: a regional analysis].
Mezhdunarodnyy zhurnal prykladnykh nauk y tekhnolohyy Integral. 2019; 1: 133-9. (Russian).

7. Nadutyy KO, Lekhan VM, Shevchenko MV. Metodychni rekomendatsiyi shchodo vyznachennya neobkhidnykh resursiv dlya dosyahnennya tsiley modernizatsiyi okhorony zdorov"ya ta napryamkiv yikh vykorystannya [Guidelines for determining the necessary resources to achieve the goals of health care necessary resources to achieve the goals of health care
modernization and areas of their use ]. Kyiv; 2013. 23 p. modernization

8. Zakon Ukrayiny vid 01.07.2010 № 2404-VI «Pro derzhavnopryvatne partnerstvo» [Law of Ukraine of 01.07.2010 № 2404-VI "On public-private partnership"] Available from: https://zakon.rada.gov.ua/laws/show/2404-17\#Text. (Ukrainian).

9. Zakon Ukrayiny vid 24.11.2015 № 817-VIII «Pro vnesennya zmin do deyakykh zakoniv Ukrayiny shchodo usunennya rehulyatornykh bar"yeriv dlya rozvytku derzhavno-pryvatnoho partnerstva ta stymulyuvannya investytsiy v Ukrayini» [Law of Ukraine of 24.11.2015 № 817-VIII "On Amendments to Certain Laws of Ukraine on Elimination of Regulatory Barriers to the Development of Public-Private Partnerships and Stimulation of Investments in Ukraine"] Available from: https://zakon.rada.gov.ua/laws/show/817-19.\#Text. (Ukrainian).

10. Zakon Ukrayiny vid 06.04.2017 № 2002-VIII «Pro vnesennya zmin do deyakykh zakonodavchykh aktiv Ukrayiny shchodo udoskonalennya zakonodavstva z pytan' diyal'nosti zakladiv okhorony zdorov'ya». [Law of Ukraine of 06.04.2017 № 2002-VIII "On Amendments to Certain Legislative Acts of Ukraine on Improving Legislation on the Activities of Health Care Institutions".] Improving Legislation on the Activities of Health Care Institutions".] 19\#Text. (Ukrainian).

\section{Реферат}

КОНЦЕПТУАЛЬНЫЕ НАПРАВЛЕНИЯ ФОРМИРОВАНИЯ МОДЕЛИ РЕГИОНАЛЬНОГО ЦЕНТРА КАРДИОЛОГИИ И КАРДИОХИРУРГИИ НА ПРИНЦИПАХ ГОСУДАРСТВЕННО-ЧАСТНОГО ПАРТНЕРСТВА Іванюк А. В.

Ключевые слова: региональный центр кардиологии и кардиохирургии, государственно-частное партнерство.

Цель исследования - Обосновать концептуальные направления фрормирования модели регионального центра кардиологии и кардиохирургии на принципах государственно-частного партнерства. Материалы и методы исследования. Для достижения поставленной цели в работе применялись об- 
щенаучные методы анализа, синтеза, обобщения, интерпретации научных данных, а также системный и структурно-функциональный подходы. Результаты. Для формирования модели регионального центра кардиологии и кардиохирургии в статье методологически выделены четыре составляющих: комплекс методов формирования модели, принципы моделирования, формирование логической структуры деятельности модели и технология моделирования. Они являются основой концептуальных направлений формирования модели регионального центра кардиологии и кардиохирургии на принципах государственно-частного партнерства, направленных на решение практической задачи организации деятельности рыночной модели регионального центра кардиологии и кардиохирургии на принципах государственно-частного партнерства. Концептуальные направления в тоже время являются и практической методологией реализации комплексного процесса моделирования регионального центра кардиологии и кардиохирургии и стратегией долгосрочного взаимодействия государства и бизнеса в решении общественно значимой задачи развития инновационной высокотехнологичной кардиологической помощи населению региона. Выводы. Концептуальные направления являются методическим инструментом для формирования современной модели медицинского учреждения с привлечением частного капитала, рыночных механизмов, обеспечивающих ей устойчивое экономическое положение и возможность развития производственной базы.

\section{Summary}

CONCEPTUAL DIRECTIONS FOR DEVELOPING MODEL OF REGIONAL CENTER OF CARDIOLOGY AND CARDIOVASCULAR SURGERY BASED ON PUBLIC-PRIVATE PARTNERSHIP PRINCIPLES

Ivanyuk V., Kiev Regional Clinical Hospital

Key words: regional center of cardiology and cardiovascular surgery, public-private partnership.

The aim of this study is to substantiate conceptual directions for developing the model of regional center of cardiology and cardiovascular surgery based on the principles of public-private partnership. Material and methods. General scientific methods of analysis, synthesis, generalization, interpretation of scientific date, as well as systemic and structural functional approaches are used in the study. Results. There have been identified four components that are the basis for the conceptual directions in developing the model of regional center of cardiology and cardiovascular, this is a set of methods for a model development, modeling principles, the logical structure formation of the model functioning and modeling technology. At the same time, the conceptual directions of the model development serve as a practical methodology for the complex process of regional center of cardiology and cardiovascular modeling implementation and a strategy for long-term collaboration between the state and business in solving the socially significant task of innovative high-tech cardiological care, which is being created for the population of the region. Conclusions. Conceptual directions serve as a methodological tool for the creation of the modern model of a medical institution with private capital, market mechanisms, ensuring a stable economic progression and the possibility of developing technical base. 